Revue scientifique francophone en Communication organisationnelle

$18 \mid 2000$

Non-verbal, communication, organisation

\title{
Le tacite à l'hôpital : formes et usages
}

\section{Emmanuel Langlois}

\section{(2) OpenEdition \\ Journals}

Édition électronique

URL : https://journals.openedition.org/communicationorganisation/2406

DOI : $10.4000 /$ communicationorganisation.2406

ISSN : $1775-3546$

Éditeur

Presses universitaires de Bordeaux

Édition imprimée

Date de publication : 1 novembre 2000

ISSN : 1168-5549

\section{Référence électronique}

Emmanuel Langlois, "Le tacite à l'hôpital : formes et usages ", Communication et organisation [En ligne], 18 | 2000, mis en ligne le 27 mars 2012, consulté le 05 août 2021. URL : http:// journals.openedition.org/communicationorganisation/2406 ; DOI : https://doi.org/10.4000/ communicationorganisation.2406

Ce document a été généré automatiquement le 5 août 2021.

(C) Presses universitaires de Bordeaux 


\section{Le tacite à l'hôpital : formes et usages}

Emmanuel Langlois 